\title{
ASSESSING THE QUALITY OF HOSPITALITY SERVICES IN TOURIST ResORTS (APPLIED ON SAFAGA CITY)
}

\author{
By \\ Shaimaa Ali Fawzy \\ Research Master Thesis \\ Faculty of Tourism and Hotels - \\ Mansoura University \\ Sherif Gamal Saad \\ Lecturer of Hotel management- \\ Faculty of Tourism and Hotels - \\ Mansoura University \\ Ahmed Hassan Metowaly \\ Ass. Prof of Hotel management- \\ Faculty of Tourism and Hotels - \\ Mansoura University

\section{Research Journal of the Faculty of Tourism and Hotels Mansoura University}

ISSUE NO. 2, DECEMBER. 2017

مجلة كلية السياحة والفنادق - جامعة المنصورة

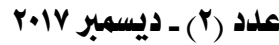


مجلة كلية السياحة والفنادق - عدد r - ديسمبر r.lv

\title{
ASSESSING THE QUALITY OF HOSPITALITY SERVICES IN TOURIST RESORTS (APPLIED ON SAFAGA CITY)
}

Shaimaa Ali Fawzy ${ }^{1}$
Sherif Gamal Saad ${ }^{2}$

\author{
Ahmed Hassan \\ Metowaly
}

\begin{abstract}
This study aims to assess the quality of hospitality services (accommodation services - food \&beverage services -staff performancerecreationservices) in a sample of tourist resorts in Safaga City. To achieve this objective, questionnaire was developed and distributed on a random sample of guests in the investigated tourist resorts. A number of 450 forms were distributed and only 396 forms (88\%) were valid to analysis.Results of the field study showed that there are many negatives that affect the quality of hospitality services (especially in food and beverages services and staff performance such as Staff uniform was not clean and did not have a good appearance and Staff did not handle guest complaints in a proper manner).
\end{abstract}

Keywords: : Hospitality service quality, spa resorts 


\section{تقييم جودة خدهات الضيافة في المنتجعات السياحية}

$$
\text { (بالتطبيق على مدينة سفاجا) }
$$

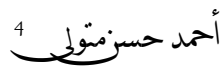

$$
\text { شريف جمالسعد5 }
$$

شيماءعلىفونع

تهدف الدراسة الحالية إلي تقييم جودة خدمات الضيافة فى المنتجعات

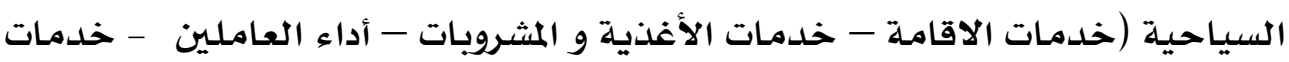
علاجية استشفائية) لمعرفة مدى تحقيق مفهوم جودة خدمات الضيافة فى المنتجعات السياحية .لتحقيق هذا الهدف قامت الباحثة بتصميم استمارة استقصاء تم توزيعها علي عينة عشوائية من السادة العملاء بالمنتجعات السياحية عينة الدراسة بلغ عددهاء


وذلك للتعرف علي أرائهم ووجهات نظرهم مِّ جودة خدمات الضيافة المقدمة إليهم. أوضحت نتائج الدراسة الميدانية أن هناك العديد من السلبيات التى تؤثر على تطبيق مفهوم الجودة و خاصة فى خدمات الاغذية و المشروبات و أداء العاملين لايجيدون حل المشكات ولا يهتمون بنظافة الزىى. الكلمات الدالة: جودة خدمات الضيافة ، المنتجعات الصحية والاستشفائية 


\section{The Research Aim}

This research aims to assess the quality of hospitality servicesaccommodation services - food \& beverage services - staff performance- recreation services) in a sample of the four and five star resorts in Safaga city. Through identifying the perceptions of resorts' customers towards quality of hospitality services provided in the investigated resorts.

\section{The Research Problem}

The problem of this study lies in answering the following question:

-What are the perceptions of the investigated customers towards hospitality services provided in Safaga resorts?

- What are the positive and negative hospitality services attributes in the investigated resorts?

\section{Review of Literature}

\section{An Overview of Resorts}

Richadson (2000) explains that a resort hotel should be located in a unique vacation spot that is desirable because of its pleasant physical surroundings, such as climate and scenery, plus its access to recreational attractions. A resort hotel should also provide indoor amenities, entertainment and other facilities to provide a superior quality of service.

\section{Spa Resort Concept}

Venter (2006) stated that improvement of health or spa resorts originated from the curative benefits of domestic mineral springs and other associated forms of treatment. Spa resorts depend on site, sport and health programs, beauty and fitness.Services, remediation of rheumatoid and other conditions, stress relief and body relaxation and dietary and weight loss. The programs period might stretch over days, 1or 2 weeks or longer.

\section{Spa Concept}

Madanoglu and Brezina, (2011) agree with Montenson and Singer (2004) stated that, the term "spa" is derived from the Latin acronym "sanities per aqua" or 'health through water'. It is also regarded as waterbased and non-water services that provide many types of treatments such as fitness, beauty, medical and relaxation.

\section{An Overview of Service Quality}

The definition of service quality has attracted the attention of many authors; Oakland (2000) perceived service quality as the way of managing business process to ensure customer satisfaction at every stage internally 
and externally. Newman (2001) defined it as the degree between customer service expectation and perception. Expectations are the wants of consumers, that is, what they feel a service provider should offer. Perceptions refer to the consumers' evaluation of the service provider. Gefen (2002) mentioned that service quality is the differences that the customers make between quality of the service that they want to receive and what they actually get.

Quality has become essential to the success of every business. The goal of quality is relatively simple and straightforward: to consistently neat or exceed customer expectations by providing products and services at prices that create value for customer and profits for the company (Woods and King, 1996).

\section{Safaga}

Safaga is situated on the western seaside of the Red Sea, close to 60 $\mathrm{Km}$ south of Hurghada, $80 \mathrm{Km}$ north of Quseir and $160 \mathrm{Km}$ east of Qena. In new times, in 1911, it became vital for exporting phosphate. Now, Safaga seaport is used to serve the pilgrims going to and from Saudi Arabia, to export aluminum and phosphate and to import wheat. The site includes many bays, and Safaga is situated on the largest one of them, opposite Safaga Island, which acts as a naturalistic barrier against great waves. Through the last few years, Safaga has proficient wonderful growth in tourism, and it has become a tourist position (Ahmed W. Mohamed, 2005)

\section{Research Methodology \\ The Research Sample}

The study originated from a need to assess the quality of hospitality services provided in a sample of resorts in Safaga city. Eight resorts were selected to conduct the study. The study was conducted on a random sample of resorts and guests to investigate their perceptions towards hospitality services provided in the investigated sample of resorts are shown in table.

Table (1): The Investigated Resorts

\begin{tabular}{|l|l|l|}
\hline \multicolumn{1}{|c|}{ Resort name } & Classification & Rooms No. \\
\hline 1- Carribean world soma bay & $5 \mathrm{star}$ & 516 \\
\hline 2- La residence des casades resort & $5 \mathrm{star}$ & 250 \\
\hline 3-Magic life resort & 5 star & 537 \\
\hline 4-Robinson club soma & $5 \mathrm{star}$ & 300 \\
\hline 5- Sheraton soma bay resort & $5 \mathrm{star}$ & 310 \\
\hline 6-Imperial shams abu soma & $4 \mathrm{star}$ & 322 \\
\hline 7- Menaville village & 4 star & 301 \\
\hline 8- Lamar Resort Abu Soma & 4 star & 316 \\
\hline
\end{tabular}


Source: Egyptian Hotel Guide (2013)

\section{Data Collection Methods}

Data in this study was collected through Customers' questionnaire form.

A self-administrated questionnaire was developed and directed to a random sample of customers in the investigated resorts to recognize their perceptions towards hospitality services provided and identify the negative and positive hospitality service attributes in the investigated properties.

\section{Result and Discussion}

\section{Analysis of Customers' Questionnaire Forms}

A total of 450 questionnaires were randomly distributed only 396 forms (88\%) were valid to analysis. Results obtained from valid forms were statically analyzed.

\section{Respondents' Profile}

These questionswere concerned with recognizing the personal data of respondents as for; gender, age and nationality.

Table (2): The Respondents' Profile

\begin{tabular}{|l|l|c|c|}
\hline \multicolumn{1}{|c|}{ Personal Data } & \multicolumn{1}{|c|}{ Attribute } & Frequency & \% \\
\hline \multirow{3}{*}{ Gender } & Male & 228 & 57.6 \\
\cline { 2 - 4 } & Female & 168 & 42.4 \\
\hline \multirow{5}{*}{ Age } & Less than 20 years & 45 & 11.4 \\
\cline { 2 - 4 } & From 20 to 40 years & 225 & 56.8 \\
\cline { 2 - 4 } & More than 40 years & 126 & 31.8 \\
\hline \multirow{5}{*}{ Nationality } & German or Deutsch & 135 & 34 \\
\cline { 2 - 4 } & Russian & 66 & 16.7 \\
\cline { 2 - 4 } & Austrian & 48 & 12 \\
\cline { 2 - 4 } & Switzerland or Swiss & 30 & 7.6 \\
\cline { 2 - 4 } & British or English & 24 & 6 \\
\cline { 2 - 4 } & Egyptian & 60 & 15.3 \\
\cline { 2 - 4 } & Others & 33 & 8.4 \\
\hline Total & & $\mathbf{3 9 6}$ & $\mathbf{1 0 0}$ \\
\hline
\end{tabular}

From the tabulated data in Table (2), it could be noticed that the majority of respondents were males (57.6\%). Meanwhile, $42.4 \%$ were females.

Concerning the age, the results revealed that $11.4 \%$ were less than 20 years; $56.8 \%$ in the category from 20 to 40 years. Meanwhile, $31.8 \%$ of respondents were more than 40 years.

In terms of respondents' nationality, 34\% were German, $16.7 \%$ and $12 \%$ were Russian and Austrian. Switzerland and British represent 7.5\% and 6\% respectively Meanwhile, $15.3 \%$ of respondents were Egyptian and $8.4 \%$ were Ukrainian, Poland, Kuwaiti, Jordanian, Saudi and Palestinian. 


\section{Table (3): The propensity to visit Safaga}

This question was designed to reveal the respondents' propensity to visit Safaga.

Table (3): The propensity to visited Safaga

\begin{tabular}{|l|c|c|}
\hline \multicolumn{1}{|c|}{ Attribute } & Frequency & \% \\
\hline One time & 72 & 33.3 \\
\hline 2-3 times & 69 & 31.9 \\
\hline More three times & 75 & 34.8 \\
\hline
\end{tabular}

From the tabulated data in Table 3 , it could be noticed that the majority of respondents $(34.8 \%)$ visited Safaga more than three times. Meanwhile, (33.3\%) visited Safaga for one time .The respondents who visited safaga from 2-3 times represent (31.9).

\section{Table (4): The Reason of the Visit}

This question was designed to the reason for the visit Safaga City.

Table (4): The reason of the visit

\begin{tabular}{|l|c|c|}
\hline \multicolumn{1}{|c|}{ Attribute } & Frequency & \% \\
\hline Recreation and sports & 141 & 35.6 \\
\hline Spa & 240 & 60.6 \\
\hline Others & 15 & 3.8 \\
\hline
\end{tabular}

Data in Table (4), revealed that the majority of respondents $(60.6 \%)$ visit Safaga for spa services and facilities .meanwhile respondents who visit Safaga for practicing recreational facilities and sports represent $35.6 \%$ only $3.8 \%$ of the investigated respondent visit Safaga for other purposes such as business and attending conferences... etc.

\section{Table (5): The Customers' Perceptions towards Quality of Resort Services}

This question was designed to reveal the respondents' perceptions towards some attributes concerning the quality of hospitality services (accommodation and room facilities - food and beverage service - recreation and entertainment facilities- staff performance) provided in a sample of resorts in Safaga City. A five point Likert scale (Strongly disagree - disagree - neutral - agree - strongly agree) was used to identify level of agreement with the attributes investigated. The range of each level of agreement was calculated as follows:

$$
\text { Range }=5-1 \div 5=0.80
$$

- $\quad$ Strongly disagree $=$ from 1.00 to 1.80 
مجلة كلية السياحة والفنادق - عدد - Pيسمبر r.IV

- $\quad$ Disagree $=$ from 1.81 to 2.60

- $\quad$ Neutral $=$ from 2.61 to 3.40

- $\quad$ Agree $=$ from 3.41 to 4.20

- $\quad$ Strongly agree $=$ from 4.21 to 5.00

The obtained results are shown in the following table.

The Respondents' Perceptions towards Hospitality Services Quality in the Investigated Resorts in Safaga city

Table (5): The Respondents' Perceptions towards Resort Services in Safaga City

\begin{tabular}{|c|c|c|c|c|c|c|c|c|c|c|c|c|}
\hline \multirow[t]{2}{*}{ Variable } & \multicolumn{2}{|c|}{$\begin{array}{l}\text { Strongly } \\
\text { disagree }\end{array}$} & \multicolumn{2}{|c|}{ Disagree } & \multicolumn{2}{|c|}{ Neutral } & \multicolumn{2}{|c|}{ Agree } & \multicolumn{2}{|c|}{$\begin{array}{l}\text { Strongly } \\
\text { agree }\end{array}$} & \multirow[t]{2}{*}{$\stackrel{3}{3}$} & \multirow[t]{2}{*}{ 第 } \\
\hline & No. & $\%$ & No. & $\%$ & No. & $\%$ & No. & $\%$ & No. & $\%$ & & \\
\hline \multicolumn{13}{|c|}{ Accommodation } \\
\hline $\begin{array}{c}\text { Guest was greeted } \\
\text { with a smile }\end{array}$ & 102 & 25.8 & 141 & 35.6 & 111 & 28 & 33 & 8.3 & 9 & 2.3 & 3.75 & 1.02 \\
\hline $\begin{array}{l}\text { Staff was } \\
\text { consistently } \\
\text { courteous }\end{array}$ & 36 & 9.1 & 57 & 14.4 & 69 & 17.4 & 135 & 34.1 & 99 & 25 & 2.52 & 1.27 \\
\hline $\begin{array}{l}\text { The staff did not } \\
\text { engage in personal } \\
\text { chat with guest }\end{array}$ & 54 & 13.6 & 96 & 24.2 & 132 & 33.3 & 90 & 22.7 & 24 & 6 & 3.19 & 1.11 \\
\hline $\begin{array}{c}\text { Rooms were clean } \\
\text { and neat }\end{array}$ & 48 & 12.1 & 36 & 9.1 & 54 & 13.6 & 150 & 37.9 & 108 & 27.3 & 2.40 & 1.30 \\
\hline $\begin{array}{c}\text { Rooms facilities } \\
\text { was fixed and tidy }\end{array}$ & 81 & 20.5 & 69 & 17.4 & 144 & 36.4 & 60 & 15.2 & 42 & 10.6 & 3.20 & 1.28 \\
\hline \multicolumn{13}{|c|}{ Food and Beverage Service } \\
\hline $\begin{array}{c}\text { Menu was } \\
\text { consisted of variety } \\
\text { items }\end{array}$ & 45 & 11.4 & 75 & 18.9 & 90 & 22.8 & 135 & 34 & 51 & 12.9 & 2.81 & 1.21 \\
\hline $\begin{array}{l}\text { Items served were } \\
\text { matching with } \\
\text { menu description }\end{array}$ & 60 & 15.2 & 72 & 18.2 & 84 & 21.2 & 93 & 23.5 & 87 & 22 & 2.91 & 1.36 \\
\hline $\begin{array}{c}\text { The price of items } \\
\text { was reasonable }\end{array}$ & 72 & 18.2 & 75 & 18.9 & 105 & 26.5 & 84 & 21.2 & 60 & 15.2 & 3.08 & 1.31 \\
\hline $\begin{array}{c}\text { Dining room was } \\
\text { clean and } \\
\text { comfortable } \\
\end{array}$ & 75 & 18.9 & 84 & 21.2 & 114 & 28.8 & 81 & 20.5 & 42 & 10.6 & 3.18 & 1.26 \\
\hline $\begin{array}{l}\text { Variety of cooking } \\
\text { methods are offered }\end{array}$ & 42 & 10.6 & 57 & 14.4 & 93 & 23.5 & 99 & 25 & 105 & 26.5 & 2.60 & 1.30 \\
\hline $\begin{array}{c}\text { Describe menu } \\
\text { items was clearly }\end{array}$ & 60 & 15.2 & 93 & 23.5 & 120 & 30.3 & 69 & 17.4 & 54 & 13.6 & 3.09 & 1.25 \\
\hline $\begin{array}{l}\text { Special meals } \\
\text { served speedy }\end{array}$ & 33 & 8.3 & 54 & 13.6 & 57 & 14.4 & 120 & 30.3 & 132 & 33.3 & 2.33 & 1.29 \\
\hline $\begin{array}{l}\text { Healthy cooking } \\
\text { methods for diet } \\
\text { and weight loss } \\
\text { programs }\end{array}$ & 93 & 23.5 & 120 & 30.3 & 48 & 12 & 72 & 18.2 & 63 & 15.9 & 3.27 & 1.41 \\
\hline $\begin{array}{l}\text { Food and beverages } \\
\text { had a good taste, } \\
\text { color and aroma }\end{array}$ & 39 & 9.8 & 78 & 19.7 & 108 & 27.3 & 117 & 29.5 & 54 & 13.6 & 32.8 & 1.20 \\
\hline
\end{tabular}


- Assessing the Quality of Hospitality Services in Tourist Resorts (Applied on Safaga City)

\begin{tabular}{|c|c|c|c|c|c|c|c|c|c|c|c|c|}
\hline $\begin{array}{c}\text { The furniture in } \\
\text { food and beverages } \\
\text { outlets was clean } \\
\text { and dust free }\end{array}$ & 123 & 31 & 111 & 28 & 84 & 21.2 & 60 & 15.2 & 18 & 4.5 & 3.67 & 1.18 \\
\hline \multicolumn{13}{|c|}{ Staff Performance } \\
\hline $\begin{array}{c}\text { Staff had the } \\
\text { knowledge to } \\
\text { answer any } \\
\text { question and } \\
\text { offering suggestion }\end{array}$ & 63 & 15.9 & 147 & 37 & 150 & 37.9 & 21 & 5.3 & 15 & 3.8 & 3.62 & 0.92 \\
\hline $\begin{array}{l}\text { Staff apologized for } \\
\text { any mistake }\end{array}$ & 33 & 8.3 & 45 & 11.4 & 69 & 17.4 & 138 & 34.8 & 111 & 28 & 2.27 & 1.21 \\
\hline $\begin{array}{l}\text { Staff uniform was } \\
\text { clean and a good } \\
\text { appearance }\end{array}$ & 45 & 11.4 & 36 & 9.1 & 39 & 9.8 & 147 & 37 & 129 & 32.6 & 2.35 & 1.34 \\
\hline $\begin{array}{l}\text { Staff had an eye } \\
\text { contact and } \\
\text { handling guest } \\
\text { complaints in a } \\
\text { proper manner }\end{array}$ & 60 & 15.2 & 96 & 24.2 & 99 & 25 & 102 & 25.8 & 39 & 9.8 & 3.11 & 1.18 \\
\hline $\begin{array}{l}\text { Staff treated } \\
\text { friendly }\end{array}$ & 45 & 11.4 & 78 & 19.7 & 162 & 40.9 & 60 & 15.2 & 51 & 12.9 & 3.02 & 1.14 \\
\hline $\begin{array}{l}\text { Staff was wearing } \\
\text { name tags }\end{array}$ & 54 & 13.6 & 81 & 20.5 & 84 & 21.2 & 87 & 22 & 90 & 22.7 & 2.83 & 1.34 \\
\hline \multicolumn{13}{|c|}{ Recreation Services } \\
\hline $\begin{array}{c}\text { Massage and steam } \\
\text { rooms were } \\
\text { comfortable }\end{array}$ & 30 & 7.6 & 60 & 15.2 & 75 & 18.9 & 111 & 28 & 120 & 30.3 & 2.37 & 1.28 \\
\hline $\begin{array}{c}\text { Swimming pool } \\
\text { was clean and neat }\end{array}$ & 51 & 12.9 & 45 & 11.4 & 90 & 22.7 & 87 & 22 & 123 & 31 & 2.53 & 1.37 \\
\hline $\begin{array}{l}\text { Beauty salon was } \\
\text { professional in all } \\
\text { facilities }\end{array}$ & 36 & 9.1 & 90 & 22.7 & 126 & 31.8 & 60 & 15.2 & 84 & 21.2 & 2.87 & 1.25 \\
\hline $\begin{array}{c}\text { Healthy and fitness } \\
\text { center (GYM) was } \\
\text { clean and } \\
\text { convenient to all } \\
\text { guests }\end{array}$ & 63 & 15.9 & 81 & 20.5 & 87 & 22 & 108 & 27 & 57 & 14.4 & 2.96 & 1.31 \\
\hline $\begin{array}{l}\text { Snorkeling trips } \\
\text { and diving were } \\
\text { enjoyable and } \\
\text { interesting }\end{array}$ & 27 & 6.8 & 57 & 14.3 & 54 & 13.6 & 114 & 28.8 & 144 & 36.3 & 2.30 & 1.27 \\
\hline $\begin{array}{l}\text { Sand baths were } \\
\text { privacy and } \\
\text { effective }\end{array}$ & 90 & 22.7 & 63 & 15.9 & 36 & 9.1 & 123 & 31 & 84 & 21.2 & 2.90 & 1.48 \\
\hline $\begin{array}{c}\text { Water sports } \\
\text { facilities (surfing, } \\
\text { sailing, kite surfing } \\
\text { and stand - up } \\
\text { paddling provided } \\
\text { as expected }\end{array}$ & 39 & 9.8 & 42 & 10.6 & 69 & 17.4 & 96 & 24.2 & 150 & 37.9 & 2.28 & 1.32 \\
\hline
\end{tabular}

As presented in Table (5) it could be noticed that the average of the Accommodation and Rooms Facilitiesattributes was ranged between 2.40 to 3.75 which mean that respondents' perceptions towards accommodation services ranged between disagree and agree. They disagreed that:

- Staff was consistently courteous (2.52) 


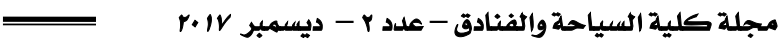

- Rooms were clean and neat (2.40)

Meanwhile, There were neutral that:

- The staff did not engage in personal chat with guest (3.19)

- Room facilities were fixed and tidy (3.20)

On the other hand they agreed that guest was greeted with a smile (3.75)

With regard to their perceptions towards food and beverages service it could be mentioned that they were disagree that:

- Variety of cooking methods are offered (2.60)

- Special meals served speedy in appropriate temperature (2.33)

On the other items ( 7 out of 10), they were neutral where the average ranged from 2.81 (Menu was consisted of variety items) to 3.27 (the Healthy cooking methods for diet and Weight loss programs).

They were neutral that menu items was clearly described (3.09), this result don't agree with that concluded by Abd Elwahab (2003) and Darwish (2016).

Also, they agreed on the furniture in food and beverages outlets were clean and dust free (3.67)

Pertaining to staff performance it could be noticed that they disagreed on:

- Staff uniform was clean and in a good appearance (2.35)

- Staff apologized for any mistake (2.27)

However, they neutral that:

- Staff had an eye contact and able to handle guest complaints in a proper manner (3.11)

- Staff was wearing name tags (2.83)

- Staff treated friendly with guests (3.02)

These results agree with that concluded by Metowaly and Saad (2016) and Darwish (2016).

On other hand they agreedthat Staff had the knowledge to answer any question and offering suggestion (3.62)

Concerning recreational service (spa and sport service) it could be noticed that, the majority of the respondents disagree that:

- Massage and steam rooms were comfortable (2.37)

- Swimming pool was clean and neat (2.53)

- Snorkeling trips and diving were enjoyable and interesting (2.30)

- Water sports facilities (surfing, sailing, kite surfing and stand - up paddling provided as expected (2.28)

Meanwhile, they were neutral that: 
- Assessing the Quality of Hospitality Services in Tourist Resorts (Applied on Safaga City)

- Beauty salon was professional in all facilities (2.87)

- Healthy and fitness center (GYM) was clean and convenient to all guests (2.96)

- Sand baths were privacy and effective (2.90)

\section{Recommendations}

1- It's important to improve food and beverages in Safagaspecially to make services more speedy and provide several food dishes with many cooking methods.

2- Tourist resorts management should take care of their room cleanness and processes of check in and check out to make guests more satisfied.

3- Conducting several training courses for resorts staff to provide them some information about method of guest treatment and staff cleanness \& hygiene.

4- Resorts management should communicate more with their guests to get accurate and reliable information for strengthening guest services such as taking care of direction signs to better meet diverse guest needs.

5- More services and facilities such as children\& business men facilities provided to increaseresort revenue and enhance guest accommodation experience.

\section{References}

- Abd Elwahab, M.G. (2008). Evaluating Food and Beverage Services in Campus. M.Sc. Thesis, Fac. of Tourism and Hotels, Helwan University.

- Ahmed W. Mohamed.(2005). Geochemistry and sedimentology of core sediments and the influence of human activities: Qusier, Safaga and Hurghada Harbors, Red Sea Coast, Egypt ,93

- Darwish, S.A. (2016). Evaluating Quality of Hospitality Services in Scouting Hostels. M.Sc. Thesis, Fac. of Tourism and Hotels, Mansoura University.

- Gefen, D. (2002), "Customer Loyalty in E-commerce", Journal of the Association for Information Systems, 3, 1, pp. 27-51.

- Egyptian Hotel Guide (2013), 33thedition Egypt.

- Ivan Venter (2006). Hotel property development: a framework for successful developments", pp.110-111 
- Madanoglu, M. and Brezina, S. (2011). Resort Spas: How are they Massaging Hotel Revenues? In O'Fallon, M.J. and Rutherford, D.G. (Eds.) "Hotel Management and Operations" - 5th Edition. John Wiley and Sons.

- Metowaly, A.H. and Saad,S.G.(2016).Assessment of quality of hotel service in youth cities, Egyptian Journal of Tourism and Hospitality, Vol.(23) No.(1).

- Monteson, P. A. and Singer, J. (2004). Marketing a resort -based SPA. Journal of Vacation Marketing.

- Newman, K. (2001), "Interrogating SERVQUAL: a Critical Assessment of Service Quality Measurement in a High Street Retail Bank", International Journal of Bank Marketing, 19, 3, pp.126 - 139.

- Okland, J. (2000), "Total Quality Management: Text with Cases", 2nd edition, Butterworth-Heinemann, Oxford

- Richadson, E. C. (2000). "Resort managment in hospitality and tourism: an introduction to the industry. 9 ed. New York: John Wiley \& Son, Inc.

- Woods, R. H. \& King, J. Z. (1996). Quality Leadership and Management in the Hospitality Industry. Educational Institute of the American Hotel and Motel Association, 1st Edition, Michigan, p. 29.

${ }^{1}$ Faculty of Tourism and Hotels Mansoura University

${ }^{2}$ Lecturer of Hotel management Faculty of Tourism and Hotels Mansoura University

${ }^{3}$ Assoc. Prof of Hotel management Faculty of Tourism and Hotels Mansoura University

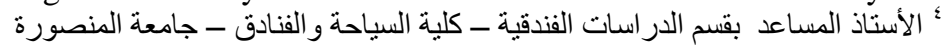

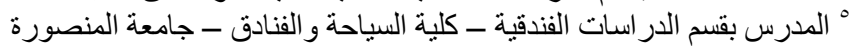
" باحثة بدرجة الماجستير - كلية السياحة والفنادق - جامعة المنصورة 